\title{
Effect of CEO Power on Malaysian Firm Performance
}

\author{
Wong Yin Theng ${ }^{1}$, Hooy Chee-Wooi ${ }^{2}$ \\ ${ }^{1}$ Public Mutual Berhad, Malaysia \\ ${ }^{2}$ School of Management, Universiti Sains Malaysia, Penang, MALAYSIA \\ Email: yintheng1992@live.com \\ DOI: https://doi.org/10.37134/jcit.vol7.6.2017
}

\begin{abstract}
This study extends the literature understanding on the role of CEO on firm performance by providing more precise measurement of CEO power. Firm performance is measured using Tobin $Q$ measure and ROA. CEO power is being proxied by using three different variables which are founder dummy, duality dummy and degree of shares ownership. The sample study involves public listed companies in Malaysia ranging from year 2001 until year 2012. The regression results show that founder CEO and CEO ownership do show negative and significant effect on Tobin $Q$. This is consistent with our hypothesis which suggests that when a company with CEO that possess high power, the firm performance will become deteriorate due to agency concern. All four control variables, which are firm size, firm age, leverage and number of segment show significant effects on Tobin $Q$. The findings remain significant even when financial crises were controlled.
\end{abstract}

Keywords CEO Power, Firm Performance, Tobin Q, Malaysia JEL classification: G30, G32, G34

\section{Introduction}

Agency theory argues that managers play a vital role in firms because they are the principal agents in firms (Jensen and Merkling, 1976). CEO is considered as the most influential and powerful actor because he is the organization's leader (Andrews, 1987 and Mintzberg, 1973). CEO leadership is also one of the important parts of a successful corporate governance mechanism, and a well-established corporate governance mechanism can enhance firm performance (Davidson III, Tong, Worrel and Rowe, 2006). Many practitioners and analysts come to a consensus that CEOs are the one who accountable for setting organizational strategy, objectives and responsible for monitoring firm performance (Dalton and Kesner, 1985). Since CEO is the representative of an organization, any changes in the CEO position or CEO decision can significantly affect investors' perception and thus affecting firm performance. Under the situation in which the CEO makes all the most relevant decisions, the risk arising from judgement errors is not well diversified (Sah and Stiglitz 1986, 1991). The probability of either a very good or a very bad decision is higher in a firm in which CEO's power is high enough to influence decisions than in a firm in which all of the top executives are involved in making decisions. That is, the higher the degree of CEO influences, the higher the variability in firm's performances.

Powerful CEO tends to make decisions with extreme consequences. The probability of either a very good or a very bad decision is higher in a firm in which CEO's power is high enough to influence decisions than in a firm in which all of the top executives are involved in 
making decisions. That is, the higher the degree of CEO influences, the higher the variability in firm's performances. Pfeffer (1997) argued that power denotes influence and control by means of overcoming resistance. More specifically, Powerful CEOs are those who can make key decisions of their firms consistently despite the potential opposition from other executives.

Public listed companies in Malaysia are practising unitary (one-tier) board structure so the board is the only highest aspect in internal corporate governance. Unlike the supervisory board of two-tier board in Germany which is theoretically more independent compared to the one-tier board, one-tier board tends to subject to groupthink (Abdullah and Ku Ismail, 2013). The power CEO possesses in a board can effectively set their own pay by influencing the paysetting process. The interest in the managerial power theory and the controversies surrounding CEO power and CEO pay can be witnessed by a host of the critiques. In spite of the diverse changes which have characterized the business environment, a majority of scholars are of the consensus that CEO power influences firm performance in the way they make strategic managerial decisions and enhancing firm performance to the best interest of the shareholders or in their self-interest. However, when we narrow down the scope to Malaysia, we found out that there is very few studies have been done to figure out the influence of CEO on firm performance in Malaysia.

In this study, we study how decision-making power of a CEO affects firm performance. "Power" is a concept that is not easily observable and has different dimensions. Finkelstein (1992) distinguish that there are four sources of power, which are structural power, ownership power, expert power, and prestige power. In this study, we follow the definition of Renee et al (2005) to focus on the structural power; the power CEO possesses over other top executives and shareholders as a result his status as a founder, status as a chairman and a CEO at the same time CEO's ownership of shares. According to Finkelstein (1992), the CEOs who are also the founder of the company would be more influential. Also, if CEO is also the chairman of the board, he is expected to have more influential over decision making since the chairman often plays a vital role in strategic decision making. This duality role was a norm in Malaysian listed companies until the release of the revised Code of Corporate Governance 2012. The duality issue has been curbedsignificantly after the new code. Ghosh (2006), find that the CEO identity with duality or related to the founder have more influence on higher board compensation. In Huang, Hsu, Khan, and Yu (2008) further discover that market responds positively to the outside director appointment especially when the CEO is also the chairman of the board, implies the concern over underlying agency problems. CEO ownership is another measure of power. It is a contentious issue on how CEO share ownership affects firm value. According to Morck, Shleifer and Vishny (1988) and McConnell and Servaes (1990), at low levels of ownership, stock ownership improves the alignment of managerial incentives with shareholder value. When beyond a certain threshold, alignment effect is dominated by the entrenchment effect. There is a hump shaped relations between insider share ownership and Tobin's Q.

The remaining of this paper is organized as follows: section 2 outlines our research methodologies and data. Section 3 the results and discussion and finally in section 4 we conclude. 


\section{Methodology and data}

Our regression model is specified as follows:

$$
\text { TOBINQ }_{i t}=\alpha+\beta_{1} \text { Size }_{i t}+\beta_{2} \text { Leverage }_{i t}+\beta_{3} \text { Age }_{i t}+\beta_{4} \text { Segment }_{i t}+\beta_{6} \text { POWER }_{i t}+\varepsilon_{i t}
$$

where the dependent variable is TOBINQ refers to Tobin's $Q$. The subject variable POWER is proxies with 3 different variables, while the remaining variables in the above models are the control variables. The $\alpha$ and $\beta$ are the parameters to be estimated, while $\varepsilon$ is the error terms. The subscript $i$ and $t$ denote the number of firms and years of the panel data.

Tobin's Q ratio was devised by James Tobin, a Nobel laureate in economics from Yale University. He hypothesized that the joined market value of all companies on the stock market should be equal to their replacement costs. Therefore, the $Q$ ratio is calculated as the market value of a company divided by the replacement value of the firm's assets. The driving factor behind investment decisions using Tobin's model is the measure of stock valuation. A high $Q$ (greater than 1) signifies that a firm's stock is more expensive than the replacement cost of its assets, implies that a stock is overvalued. On the other hand, a low $Q$ (between 0 and 1) signifies that the cost to replace a firm's assets is greater than the value of the stock, implies that the stock is undervalued.

We include 4 control variables comprises of Size (natural log of firm's assets), Leverage (book value of long term debt divided by book assets), Age (number of years since the firm was corporated) and Segment (number of segments that the firm diversified to). We follow Barnhart et al. (1998) and Hermalin et al. (1991) to use the natural logarithm of total assets as a proxy for the size of a firm. Firm size has been found to be related to various firm characteristics. Himmelberg, Hubbard and Palia (1999) proposed that larger firms incur higher monitoring and agency costs; while Lang and Stulz (1994) found a negative relationship between firm size and Tobin's $Q$.

Leverage is defined as the debts to asset ratio. A firm with higher leverage should be most incited to improve their performance. Yet a higher leverage means higher agency costs because of the diverging interests between shareholders and debtholders. According to Jensen and Meckling (1976) and Myers (1977), the moral hazard problem suggests that leverage may be negatively linked to performance. Hence, literature claims that there is an opposite argument on the relationship between leverage and performance. However, a survey of the empirical literature shows the lack of consensus on the link between leverage and corporate performance.

There are three specific theoretical predictions for how firm age affects firm performance. We summarise these theoretical predictions in terms of selection effects, learning-by-doing effects, and inertia effects. Selection effects arise when selection pressures progressively eliminate the weakest firms, and result in an increase in the average productivity level of surviving firms, even if the productivity levels of individual firms do not change with age. According to Jovanovic (1982), firms are born with fixed productivity levels and learn about their productivity levels as time passes. Learning-by-doing effects can be expected to be relevant for start-up firms (Garnsey, 1998). When firms learn about more productive production techniques and incorporate the improvements in their production routines, the firms are expected increase in their productivity (Arrow, 1962 and Vassilakis, 2008). Inertia effects state that as firms get older, they might become less productive and competitive if they 
become increasingly inert and inflexible. Older firms are prone to suffer from a "liability of obsolescence" because they do not adapt well to the continuous changing environment (Barron et al., 1994).

The number of segments is the number of business segments at selected companies. We followed Renee et al (2005) which employ the number of segments as a control variable for firm performance. The firm business segment data is gathered from Datastream and according to its industry segmentation. Generally, most literature shows that diversification has discounted firm value, as shown in Berger and Ofek (1995), Lang and Stulz (1994) and Servaes (1996) as more business segment will cause the capital being allocated inefficiently across different parts. Lamont (1997) proves that inefficient investment patterns by transferring cash flows between division causing some of the business to be overfunded and some to be underfunded. Firm value could be dragged by the administrative cost associated with the internal capital market (Baker, 1992). However, some argue that business diversification should bring positive effect on firm performance when managers do not have any private information about the segment in their company, which will cause no information asymmetry (Hadlock et al., 1999). Diversity of cash flow variation is positive by reducing the volatility of cash flow and the probability of financial distress (Lewellen, 1971).

POWER is used to denote the CEO power. We follow Renee et al (2005) to have the 3 proxies for power included. The first measure is a dummy variable that indicates whether CEO is also one of the founders of the company. Founder dummy is equals to one if CEO is also the founder of the company. The dummy will equal to zero otherwise. The second measure is a dummy variable that measures the duality role of the CEO. Duality dummy equals to one if CEO is also the chairman of the company. The dummy will equal to zero otherwise. The third measure is CEO ownership in a company. CEO ownership consists of direct shareholdings and indirect shareholdings. Direct shareholdings mean it is owned by a private individual, in his own name, which is CEO in this case. Indirect shareholdings represent stocks that are not in an individual's name but rather held by a subsidiary or third party. This information is all available in the annual reports.

Our samples include public listed companies in Malaysia ranges from year 2001 to year 2012. To construct firm performance variables which are dependant variables in the study, we need to compute Tobin's $Q$ for each public listed company, ROA and stock returns used to verify the robustness of our results. To construct CEO power proxy indicators, CEO ownership, founder, CEO duality of each public listed company in Malaysia are needed. To construct control variables, assets in billions, leverage, number of segments and firm age that owned by the respective companies are required. The information pertaining to board characteristics were obtained from the annual reports. Firms with insufficient director and financial data were excluded from the regression analysis. 
Table 1 Descriptions of Variables

\begin{tabular}{|c|c|}
\hline Variable Name & Variable Description \\
\hline \multicolumn{2}{|c|}{$\underline{\text { Dependent Variables }}$} \\
\hline TOBINQ & Market value of a company divided by the replacement value of the firm's assets. \\
\hline \multicolumn{2}{|c|}{ Independent Variables } \\
\hline Founder & Founder dummy equals to one if CEO is also the founder of the company. \\
\hline Duality & Duality dummy equals to one if CEO is also the chairman of the company. \\
\hline MOwner & CEO ownership equals to total direct ownership plus total indirect ownership in percentage form \\
\hline \multicolumn{2}{|c|}{ Control Variables } \\
\hline $\ln ($ Asset $)$ & Natural logarithm of total assets as proxy for the size of a firm. \\
\hline Leverage & Ratio of total debts over total assets. \\
\hline Age & Number of years of a company since the date of corporation. \\
\hline Segment & Number of segments that a company diversified to. \\
\hline
\end{tabular}

\section{Results and discussions}

\subsection{Descriptive Statistics}

Table 2 shows the descriptive statistics of all the important variables used in this study. We can see that many CEO in Malaysia firm is also the founder of the company, with the mean of the founder dummy equal to 0.258 . This is quite high relative to companies in western countries; Renee et al (2005) for example reported the mean of founder dummy is only 0.09 based on 336 Fortune 500 companies. The mean of duality dummy however is only 0.127 as compared to 0.41 in Renee et al (2005). For control variables, we can see that Malaysia companies generally are in high leverage but the minimum value of zero implies that there are companies do not use leverage at all. The oldest firm in our sample has the age of 111 years. On average, Malaysia companies also generally diverged into many segments having 2.675 as mean in the number of segments.

Table 2 Descriptive Statistics of All Variables

\begin{tabular}{lrrrrrr}
\hline & mean & median & sd & $\min$ & $\max$ & $\mathrm{N}$ \\
\hline Dependant Variables & & & & & & \\
TOBINQ & 1.125 & 0.924 & 0.926 & 0.208 & 16.691 & 10837 \\
ROA & 0.025 & 0.037 & 0.186 & -5.812 & 2.029 & 11486 \\
POWER Variables & & & & & & \\
Founder & 0.258 & 0.000 & 0.437 & 0.000 & 1.000 & 3229 \\
Duality & 0.127 & 0.000 & 0.334 & 0.000 & 1.000 & 3499 \\
MOwner & 0.131 & 0.001 & 0.199 & 0.000 & 0.800 & 3185 \\
Control Variables & & & & & & \\
ln(Asset) & 12.857 & 12.626 & 1.546 & 2.303 & 20.017 & 10328 \\
Leverage & 0.239 & 0.186 & 0.314 & 0.000 & 6.721 & 11515
\end{tabular}




\begin{tabular}{lrrrrrr} 
Age & 24.057 & 20.000 & 17.227 & 1.000 & 111.000 & 10561 \\
Segment & 2.675 & 2.000 & 1.553 & 1.000 & 9.000 & 9132 \\
\hline
\end{tabular}

Note: The descriptions of all variables inside this table are provided in Table 1.

Table 2 Descriptive Statistics of All Variables

\begin{tabular}{|c|c|c|c|c|c|c|}
\hline \multicolumn{7}{|c|}{ Full Sample (1) } \\
\hline stats & mean & p50 & sd & $\min$ & $\max$ & $\mathrm{N}$ \\
\hline \multicolumn{7}{|c|}{ Dependent Variables } \\
\hline TOBINQ & 1.086 & 0.897 & 0.842 & 0.208 & 13.075 & 3481 \\
\hline ROA & 0.057 & 0.049 & 0.099 & -1.224 & 2.029 & 3475 \\
\hline \multicolumn{7}{|c|}{ Independent Variables } \\
\hline Founder & 0.258 & 0.000 & 0.437 & 0.000 & 1.000 & 3229 \\
\hline Duality & 0.127 & 0.000 & 0.334 & 0.000 & 1.000 & 3499 \\
\hline Mowner & 0.131 & 0.001 & 0.199 & 0.000 & 0.800 & 3185 \\
\hline \multicolumn{7}{|c|}{ Control Variables } \\
\hline $\ln$ (Asset) & 13.339 & 13.112 & 1.318 & 8.239 & 18.298 & 3492 \\
\hline Debta & 0.195 & 0.168 & 0.177 & 0.000 & 2.028 & 3492 \\
\hline Age & 28.447 & 26.000 & 17.758 & 2.000 & 105.000 & 3499 \\
\hline Segment & 2.874 & 3.000 & 1.618 & 1.000 & 9.000 & 3219 \\
\hline
\end{tabular}

Note: The descriptions of all the variables inside this table are provided in Table 1.

In Table 3 we report the descriptive statistics for the sample of firms with and without founding CEO, as well as for the sample of firms with and without duality. Performance wise, firms with founding CEO generally has a significantly lower Tobin's Q. However, ROA of firms with founding CEO is not that different with those of firms with non-founding CEO statistically. Also, firms with duality CEO also do not exhibit significant different performance in both Tobin's $Q$ and ROA as compared to firms without duality CEO. Interestingly, we can observe that firms with founding CEO tend to have duality role and higher CEO share ownership so as firms with firms with CEO duality also poses more founding CEO and CEO share ownership. The differences also appear in other firm fundamentals like firm size and age for firms with founding CEO, as well as age and business segment for firms with duality CEO. The correlations of the variables are reported in Table 4. Basically, multicollinearity is not an issue. Besides we also use VIF indicators to prove that there is no multicollinearity in our model estimation. 
Table 3 T-test using Founder and Duality

\begin{tabular}{|c|c|c|c|c|c|c|c|c|c|c|}
\hline & & & 3 & & \multirow{3}{*}{$\begin{array}{l}\text { Difference } \\
\text { between } \\
\text { (1) \& (2) } \\
\text { (t-test) }\end{array}$} & 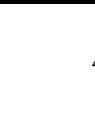 & & & & \multirow{3}{*}{$\begin{array}{l}\text { Difference } \\
\text { between } \\
(3) \&(4) \\
\text { (t-test) }\end{array}$} \\
\hline & \multicolumn{2}{|c|}{ founder $=1$} & \multicolumn{2}{|c|}{ founder $=0$} & & \multicolumn{2}{|c|}{ duality $=1$} & \multicolumn{2}{|c|}{ duality $=0$} & \\
\hline & mean & $\mathrm{N}$ & mean & $\mathrm{N}$ & & mean & $\mathrm{N}$ & mean & $\mathrm{N}$ & \\
\hline \multicolumn{11}{|c|}{ Dependant Variables } \\
\hline TOBINQ & 1.016 & 831 & 1.138 & 2383 & $-0.122^{* * *}$ & 1.097 & 446 & 1.086 & 3012 & 0.010 \\
\hline \multicolumn{11}{|c|}{ Independent Variables } \\
\hline Founder & 1.000 & 832 & 0.000 & 2397 & NIL & 0.504 & 421 & 0.221 & 2784 & $0.282^{* * *}$ \\
\hline Duality & 0.256 & 828 & 0.088 & 2377 & $0.168^{* * *}$ & 1.000 & 446 & 0.000 & 3053 & NIL \\
\hline MOwner & 0.268 & 694 & 0.127 & 1780 & $0.141^{* * *}$ & 0.290 & 271 & 0.152 & 2201 & $0.137^{* * *}$ \\
\hline \multicolumn{11}{|c|}{$\underline{\text { Control Variables }}$} \\
\hline $\ln$ (Asset) & 13.046 & 832 & 13.404 & 2390 & $-0.359^{* * *}$ & 13.406 & 446 & 13.333 & 3022 & 0.073 \\
\hline Leverage & 0.197 & 832 & 0.195 & 2390 & 0.002 & 0.196 & 446 & 0.195 & 3022 & 0.001 \\
\hline Age & 21.183 & 832 & 30.669 & 2373 & $-9.486^{* * *}$ & 26.141 & 446 & 28.529 & 3029 & $-2.388^{* * *}$ \\
\hline Segment & 2.947 & 770 & 2.878 & 2208 & 0.069 & 3.178 & 393 & 2.828 & 2806 & $0.350^{* * *}$ \\
\hline
\end{tabular}

Note: The descriptions of all variables inside this table are provided in Table $1 .{ }^{* * * *},{ }^{* * *}$ and ${ }^{*}$ denote statistical significance at the $1 \%, 5 \%$ and $10 \%$ levels, respectively. $\mathrm{N}$ is the number of observations.

Table 4 Correlation Matrix

\begin{tabular}{lcccccccc}
\hline & TOBINQ & $\ln$ (Asset) & Leverage & Age & Segment & Founder & Duality & MOwner \\
\hline TOBINQ & 1 & & & & & & & \\
$\ln$ (Asset) & 0.1235 & 1 & & & & & & \\
Leverage & 0.0202 & 0.3716 & 1 & & & & & \\
Age & 0.0719 & 0.2928 & 0.0886 & 1 & & & & \\
Segment & -0.1841 & 0.438 & 0.2561 & 0.1812 & 1 & & & \\
Founder & -0.0808 & -0.1818 & -0.0671 & -0.2185 & -0.0418 & 1 & & \\
Duality & -0.018 & -0.0054 & -0.0654 & -0.0628 & 0.0194 & 0.235 & 1 & \\
MOwner & -0.1528 & -0.2636 & -0.1293 & -0.1286 & -0.0509 & 0.2758 & 0.203 & 1 \\
\hline
\end{tabular}

Note: The descriptions of all variables inside this table are provided in Table 1. 


\subsection{Regression Results and Robustness Test}

\subsubsection{Estimates for the Baseline Regression Model}

Table 5 shows the OLS regression model with White standard error. Two of the proxies show significant and negative effect on Tobin's $Q$ where FOUNDER and MOWNER show significant level at $1 \%$ statistically. The results shown are consistent with our hypothesis which postulates that CEO power will negatively affect firm performance in Malaysia. The result of our study is different with the study of Renee et al (2005) on 336 publicly traded, nonregulated firms from the 1998 Fortune 500. The result of Renee et al study shows positive correlation between CEO power and performance variability. This is probably due to the facts that companies that are listed in Fortune 500 are all successful companies with professional CEO. In the case of Malaysia, the concern of Type II agency problem exists and when CEO holds more power, the chances is firm performance is not going to be better. The insignificant of CEO duality dummy could be due to the fact that even the duality issue was only addressed formally in Malaysian's Code of Corporate Governance 2012, the issue has been under scrutiny in the industry even before the recommendation was made public. As illustrated in Table 2, the number of firms with CEO duality is not a lot in the sample and TOBINQ value does not significantly differ for firm with and without CEO duality. In fact, the insignificant relationship between CEO duality and Tobin's Q, also found by Vintilă, Onofrei, \&Gherghina (2015) in Romania public listed companies.

Table 5 Estimates on Baseline Model Based on Tobin's Q

This table employs white standard error on OLS model of Tobin Q. Column (1) includes only control variables while column (2), (3), (4) includes control variables and different CEO power proxies which are FOUNDER, DUALITY and MOWNER. The descriptions of all variables inside this table are provided in Table 1. The regressions in this table are based on following equation:

TOBINQ $_{i t}=\alpha+\beta_{1} \ln \left(\right.$ Asset $\left._{i t}\right)+\beta_{2}$ Leverage $_{i t}+\beta_{3}$ Age $_{i t}+\beta_{4}$ Segment $_{i t}+\beta_{5}$ POWER $_{i t}+\varepsilon_{i t}$

\begin{tabular}{lcccc}
\hline & $(1)$ & $(2)$ & $(3)$ & $(4)$ \\
\hline constant & $0.5567^{* * *}$ & $-0.2768^{*}$ & -0.178 & $0.1938^{*}$ \\
& $(0.0814)$ & $(0.1557)$ & $(0.1484)$ & $(0.1062)$ \\
$\ln ($ Asset $)$ & $0.0392^{* * *}$ & $0.1429^{* * *}$ & $0.1267^{* * *}$ & $0.0981^{* * *}$ \\
& $(0.0076)$ & $(0.0142)$ & $(0.0135)$ & $(0.0090)$ \\
Leverage & $0.6989^{* * *}$ & -0.1686 & -0.1276 & -0.0317 \\
& $(0.1130)$ & $(0.1047)$ & $(0.1011)$ & $(0.0940)$ \\
Age & 0.0005 & $-0.0024^{* * *}$ & $-0.0018^{* *}$ & 0.0004 \\
Segment & $(0.0005)$ & $(0.0008)$ & $(0.0008)$ & $(0.0008)$ \\
& $-0.0774^{* * *}$ & $-0.1375^{* * *}$ & $-0.1229^{* * *}$ & $-0.1307^{* * *}$ \\
POWER(Founder)) & $(0.0066)$ & $(0.0128)$ & $(0.0119)$ & $(0.0123)$ \\
& & $-0.1101^{* * *}$ & & \\
POWER(Duality) & & $(0.0234)$ & &
\end{tabular}


POWER(MOwner)

$-0.3230^{* * *}$

(0.0546)

\begin{tabular}{ccccc}
\hline $\mathrm{N}$ & 7535 & 2950 & 3171 & 2859 \\
Adjusted $\mathrm{R}^{2}$ & 0.0853 & 0.0778 & 0.0613 & 0.0747 \\
$\mathrm{R}^{2}$ & 0.0858 & 0.0794 & 0.0627 & 0.0763 \\
\hline
\end{tabular}

Note: Standard error of each coefficient is reported in parentheses. These are heteroskedasticity adjusted standard error suggested by White (1980). N denotes number of observations. ${ }^{* * * * * *}$ and ${ }^{*}$ denote statistical significance at the $1 \%, 5 \%$ and $10 \%$ levels, respectively. We applied VIF indicator to check whether our baseline regression models have multicollinearity problems. The VIF value is expected to be less than 5 to indicate no serious multicollinearity problem (O'Brien, 2007). To conserve space, we do not report the VIF value for each variable in all the 3 models. All the VIF values in our models are less than 5, with the highest of 1.31 on Size, implying no serious multicollinearity problem presents in our estimated models.

For the control variables, we documented firm size has positive and significant effect on Tobin's Q, but Renee et al (2005) show firm size has negative effect on Tobin's Q. We argued that the different could be due to the fact that Fortune 500 firms already reached its maximum capacity and hence further expansion of size may weaken performance. When we include POWER dummies, leverage turned negative but insignificant effect on Tobin's Q. Age shows negative and has significant effect on Tobin's $Q$ in both (2) and (3) regression model, consistent with Renee et al (2005). Number of segment shows negative and has significant effect on Tobin's $Q$ in all regression models implying diversification is contributing to Malaysian firm performance.

\subsubsection{Controlling for Financial Crisis}

The dynamic nature of worldwide economic environment makes the estimation becomes complicated. To control for the financial crisis, we add three crisis dummy variables for all the observations in Year 2008 and Year 2009. The crisis 1 we used is Dot-Com Bubble that happened in year 2001. Crisis 2 is the US Subprime Crisis that happened from year 2008 to year 2009 and Crisis 3 is the European Debt Crisis that happened from year 2011 to year 2012. The estimated result is reported in Table 6. 


\section{Table 6: Estimates with Crisis Dummy for Tobin $Q$}

This table adds in crisis dummies for OLS model. Column (1) includes only control variables while column (2), (3), (4) includes control variables and different CEO power proxies which are FOUNDER, DUALITY and MOWNER. The descriptions of all variables inside this table are provided in Table 1. The regressions in this table are based on following equation:

$$
\begin{aligned}
& \text { TOBINQ }_{i t}=\alpha+\beta_{1} \ln \left(\text { Asset }_{i t}\right)+\beta_{2} \text { Leverage }_{i t}+\beta_{3} \text { Age }_{i t}+\beta_{4} \text { Segment }_{i t}+\beta_{5} \text { POWER }_{i t} \\
& +\beta_{6} \text { Crisis }_{i t}+\beta_{7} \text { Crisis }_{i t}+\beta_{8} \text { Crisis }_{i t}+\varepsilon_{i t}
\end{aligned}
$$

\begin{tabular}{|c|c|c|c|c|}
\hline & $(1)$ & (2) & (3) & $(4)$ \\
\hline \multirow[t]{2}{*}{ constant } & $0.5726^{* * *}$ & -0.2684 & -0.1646 & 0.221 \\
\hline & $(0.0706)$ & $(0.1636)$ & $(0.1536)$ & $(0.1476)$ \\
\hline \multirow[t]{2}{*}{$\ln ($ Asset $)$} & $0.0402^{* * *}$ & $0.1445^{* * *}$ & $0.1275^{* * *}$ & $0.0977^{* * *}$ \\
\hline & $(0.0060)$ & $(0.0133)$ & $(0.0126)$ & $(0.0118)$ \\
\hline \multirow{2}{*}{ Leverage } & $0.6957^{* * *}$ & $-0.1679^{*}$ & -0.1223 & -0.028 \\
\hline & $(0.0298)$ & $(0.0921)$ & $(0.0882)$ & $(0.0826)$ \\
\hline \multirow[t]{2}{*}{ Age } & 0.0007 & $-0.0023^{* * *}$ & $-0.0018^{* *}$ & 0.0004 \\
\hline & $(0.0005)$ & $(0.0009)$ & $(0.0008)$ & $(0.0008)$ \\
\hline \multirow[t]{2}{*}{ Segment } & $-0.0794^{* * *}$ & $-0.1388^{* * *}$ & $-0.1241^{* * *}$ & $-0.1308^{* * *}$ \\
\hline & $(0.0054)$ & $(0.0101)$ & $(0.0095)$ & $(0.0097)$ \\
\hline \multirow[t]{2}{*}{ Crisis1 } & 0.0164 & -0.0344 & -0.033 & -0.0705 \\
\hline & $(0.0298)$ & $(0.0575)$ & $(0.0535)$ & $(0.0575)$ \\
\hline \multirow[t]{2}{*}{ Crisis2 } & $-0.1550^{* * *}$ & $-0.1598^{* * *}$ & $-0.1505^{* * *}$ & $-0.1243^{* * *}$ \\
\hline & $(0.0214)$ & $(0.0416)$ & $(0.0392)$ & $(0.0395)$ \\
\hline \multirow[t]{2}{*}{ Crisis3 } & -0.0179 & 0.0117 & 0.034 & 0.034 \\
\hline & $(0.0228)$ & $(0.0422)$ & $(0.0404)$ & $(0.0406)$ \\
\hline \multirow[t]{2}{*}{ POWER(Founder)) } & & $-0.1096^{* * *}$ & & \\
\hline & & $(0.0351)$ & & \\
\hline \multirow[t]{2}{*}{ POWER(Duality) } & & & -0.0127 & \\
\hline & & & $(0.0430)$ & \\
\hline \multirow[t]{2}{*}{ POWER(MOwner) } & & & & $-0.3241^{* * *}$ \\
\hline & & & & $(0.0739)$ \\
\hline $\mathrm{N}$ & 7535 & 2950 & 3171 & 2859 \\
\hline Adjusted $\mathrm{R}^{2}$ & 0.0916 & 0.082 & 0.0657 & 0.0781 \\
\hline $\mathrm{R}^{2}$ & 0.0925 & 0.0845 & 0.068 & 0.0807 \\
\hline
\end{tabular}

Note: Standard error of each coefficient is reported in parentheses. $\mathrm{N}$ denotes number of observations. ${ }^{* * * * * *},{ }^{* *}$ and ${ }^{*}$ denote statistical significance at the $1 \%, 5 \%$ and $10 \%$ levels, respectively.

From Table 6, we observed that the significant level of all CEO proxy still remains unchanged. The FOUNDER and MOWNEER proxy remained at significant 1\%. As a result, we can conclude that the result remains robust after accounting for crisis. Only crisis 2 poses significant effect. The US Subprime Crisis that happened from year 2008 to year 2009 poses a negative and significant effect on firm performance. Crisis 1 and 3 do not pose any significant 
effect on firm performance. This is because US Subprime Crisis had a ripple effect that affects almost every country in the world.

\section{Conclusion}

This study explores the effects of CEO power on firm value based on a sample of 295 listed firm in Bursa Malaysia from 2001 to 2012. We defined CEO power with 3 different proxies comprises a founder dummy, a duality dummy and an ownership variable. Using panel regression, we find that only two of the CEO power proxies, i.e. founder CEO and CEO ownership show negative and significant effect on firm performance which is measured by Tobin Q. This is consistent with our hypothesis which suggests that when a company with CEO that possess high power, the firm performance will become deteriorate. This is likely due to agency problem in Malaysian family firms which predominantly has powerful CEO. Most of the control variables used in this study show significant results to firm performance which are suggested by the previous literature. Lastly, when we control for the 2001, 2008 and 2011 financial crises, the same two power proxies, which are founder dummy and CEO ownership remain significant. Future study could drill further on the issue of CEO power by looking at the influence of CEO's social and human capital, as well as its dominancy over the board of directors. We believe that the findings will shed lights to enhance corporate governance setting particularly in family firms as the case in Malaysia.

\section{References}

Abdullah, S. \& Ku Ismail, K. (2013). Gender, ethnic and age diversity of the boards of large Malaysian firms and performance. Jurnal Pengurusan, 38, 27-40.

Andrews, K. (1987). The concept of corporate strategy. Dow-Jones. Homewood, IL: Irwin.

Arrow, K.J. (1962). The economic implications of learning by doing. Review of Economic Studies, 29, 155-73.

Baker, G. (1992). Beatrice: A study in the creation and destruction of value. Journal of Finance, 47, 1081-1119.

Barnhart, S. \& Rosenstein, S. (1998). Board composition, managerial ownership, and firm performance: An empirical analysis. The Financial Review, 33 (4), 1-16.

Barron, D. N., West, E. \& Hannan, M. T. (1994). A time to growth and a time to die: Growth and mortality of credit unions in New York, 1914-1990. American Journal of Sociology, 100 (2), 381-421.

Berger, P. \& Ofek, E. (1995). Diversification's effect on firm value. Journal of Financial Economics, 37, $39-66$.

Dalton, D. R. \& Kesner, I. F. (1985). Inside/outside succession and organizational size: The pragmatics of executive replacement. Academy of Management Journal, 26.

Davidson III, W. N., Tong, S., Worrel, D. L. \& Rowe, W. (2006). Ignoring rules of succession: How the board reacts to CEO illness announcements. Journal of Business Strategies, 23, 93-117.

Finkelstein, S. (1992). Power in top management teams: Dimensions, measurement, and validation. Academy of Management Journal, 35, 505-538.

Garnsey, E. (1998). A theory of the early growth of the firm. Industrial and Corporate Change, 7 (3), 523-556.

Ghosh, A. (2006). Determination of Executive Compensation in an Emerging Economy. Evidence from India. Emerging Markets Finance and Trade, 42(3), 66-90. doi: 10.2753/REE1540-496X420304

Hadlock, C., Ryngaert, M. \& Thomas, S. (1999). Corporate structure and equity offerings: Are there benefits to diversification?"Unpublished Working Paper, Michigan State University, Michigan.

Hermalin, B. E. \& Weisbach, M. S. (1991). The effects of board composition and direct incentives on firm performance. Financial Management, 20 (4), 101-12.

Himmelberg, Charles P., R. Glenn Hubbard \& Darius Palia (1999). Understanding the determinants of managerial ownership and the link between ownership and performance. Journal of Financial Economics, 53, 353-384. 
Huang, H.-H., Hsu, P., Khan, H. A., \& Yu, Y.-L. (2008). Does the appointment of an outside director increase firm value? Evidence from Taiwan. Emerging Markets Finance and Trade, 44(3), 66-80. doi: 10.2753/REE1540496x440305.

Jensen, M. \& Meckling, W. (1976). Theory of the firm: Managerial behaviour, agency costs, and ownership structure. Journal of Financial Economics, 3, 305-360.

Jovanovic, B. (1982). Selection and the evolution of industry. Econometrica, 50(3), 649-670.

Lamont, O. (1997). Cash flow and investment: Evidence from internal capital markets. Journal of Finance, 52, 83-109

Lang, L., \& René M. Stulz (1994). Tobin's Q, corporate diversification and firm performance. Journal of Political Economy, 102, 1248-1280.

Lewellen, W. (1971). A pure financial rationale for the conglomerate merger. Journal of Finance, 26,521-537.

McConnell, John J. \& Henri Servaes. (1990). Additional evidence on equity ownership and corporate value. Journal of Financial Economics, 27, 595-612.

Mintzberg, H. (1973). The Nature of Managerial Work. New York: Harper and Row.

Morck, R., A. Shleifer, \& R.W. Vishny. (1988). Characteristics of targets of hostile and friendly takeovers. In: A.J. Auerbach (Eds), Corporate Takeovers: Causes and Consequences. University of Chicago Press, Chicago, IL.

Myers, S.C. \& S.M. Turnbull. (1977). Capital budgeting and the Capital Asset Pricing Model: Good news and bad news. Journal of Finance, 32, 321-333.

O'Brien, R.M. (2007). A caution regarding rule of thumb for variance inflation factors. Quality and Quantity, 41, 67390.

Pfeffer, J. (1997). New directions for Organization Theory: Problems and prospects. Oxford University Press, New York.

Renée B Adams, Heitor Almeida, \& Daniel Ferreira. (2005). Powerful CEOs and their impact on corporate performance. Review of Financial Studies, 18(4), 1403-1432.

Sah, R. K., \& J. Stiglitz. (1986). The architecture of economic systems: Hierarchies and polyarchies. American Economic Review, 76, 716-27.

Sah, R. K., \& J. Stiglitz. (1991). The quality of managers in centralized versus decentralizedorganizations. Quarterly Journal of Economics, 106, 289-295.

Servaes, H. (1996). The value of diversification during the conglomerate merger wave. Journal of Finance, 51, 12011225.

Vassilakis, S. (2008). Learning-by-doing. In: The New Palgrave Dictionary of Economics", Second Edition. (Eds) Steven N. Durlauf and Lawrence E. Blume. Palgrave Macmillan.

Vintilă, G., Onofrei, M., \& Gherghina, Ş. C. (2015). The effects of corporate board and CEO characteristics on firm value: empirical evidence from listed companies on the Bucharest Stock Exchange. Emerging Markets Finance and Trade, 51(6), 1244-1260.

White, H. (1980). A heteroskedasticity-consistent covariance matrix estimator and a direct test for heteroskedasticity. Econometrica, 48, 817-838. 